\title{
Erratum to: Diagnosis of anterior commissure invasion in laryngeal cancer
}

\author{
Baris Naiboglu • Vefa Kinis • Sema Zer Toros • \\ Tulay Erden Habesoglu • Ildem Deveci • \\ Mehmet Surmeli • Erol Egeli
}

Published online: 2 April 2013

(C) Springer-Verlag Berlin Heidelberg 2013

\section{Erratum to: Eur Arch Otorhinolaryngol (2010)}

\section{7:551-555}

DOI 10.1007/s00405-009-1124-3

Unfortunately, there are two inadvertent mistakes in "Materials and methods". The beginning date of the case series should be March 2003 instead of March 2006. The number of patients who had undergone total laryngectomy and partial laryngectomy should be 36 and 11, respectively.

The online version of the original article can be found under doi:10.1007/s00405-009-1124-3.

B. Naiboglu • V. Kinis · S. Z. Toros · T. E. Habesoglu • I. Deveci ·

M. Surmeli · E. Egeli

Department of Otolaryngology,

Haydarpasa Numune Education and Research Hospital,

Istanbul, Turkey

B. Naiboglu ( $\square)$

Acıbadem Yaprak Sokak, Altınturk apt. No. 39/8,

34668 Uskudar, Istanbul, Turkey

e-mail: drbnaib@yahoo.com 